Safundi

The Journal of South African and American Studies

ISSN: 1753-3171 (Print) 1543-1304 (Online) Journal homepage: http://www.tandfonline.com/loi/rsaf20

\title{
Coetzee's stones: Dusklands and the nonhuman witness
}

\section{Daniel Williams}

To cite this article: Daniel Williams (2018): Coetzee's stones: Dusklands and the nonhuman witness, Safundi, DOI: 10.1080/17533171.2018.1472829

To link to this article: https://doi.org/10.1080/17533171.2018.1472829

曲 Published online: 21 Jun 2018.

Submit your article to this journal ¿

Q View related articles $\sqsubset$

View Crossmark data $₫$ 


\title{
Coetzee's stones: Dusklands and the nonhuman witness
}

\author{
Daniel Williams \\ Society of Fellows, Harvard University, Cambridge, MA, USA
}

\begin{abstract}
Bringing together theoretical writing on objects, testimony, and trauma to develop the category of the "nonhuman witness," this essay considers the narrative, ethical, and ecological work performed by peripheral objects in J. M. Coetzee's Dusklands (1974). Coetzee's insistent object catalogues acquire narrative agency and provide material for a counter-narrative parody of first-personal reports of violence in Dusklands. Such collections of nonhuman witnesses further disclose the longer temporality of ecological violence that extends beyond the text's represented and imagined casualties. Linking the paired novellas of Dusklands, which concern 1970s America and 1760s South Africa, the essay finds in Coetzee's strange early work a durable ethical contribution to South African literature precisely for its attention to nonhuman claimants and environments.
\end{abstract}

\section{KEYWORDS}

J. M. Coetzee; testimony; nonhuman; objects; ecocriticism; postcolonialism

Across fields like science studies, continental philosophy, and political theory, readers have in recent years become familiar with moments where a text stalls into parataxis and offers, often without commentary, a list: "sunspots, thalwegs, antibodies, carbon spectra"; "black, white and blue porcelain beads, tobacco, knives, looking-glasses, brass wire." Variously characterized as compendia, bestiaries, and litanies, these exuberant displays of aggregation have been replicated in projects with markedly oppositional attitudes towards the entities they bring forward in support of metaphysical or political programs. ${ }^{2}$

The nonhuman world we do not usually think of as speaking or witnessing, but such fantasies are necessarily entailed by the turn to objects. What are these listed items saying to us? In what theoretical ceremony do things perform their litanies? To what does matter testify? Convening a vibrant ensemble of nonhumans, incantatory lists revive a tradition that echoes from scriptural writing through Romantic poetics and beyond. The nonhuman has long been exhorted to bear witness to human actions and avocations. "Make a joyful noise unto the LORD, all the earth," runs Psalm 98: "Let the floods clap their hands: let the hills be joyful together." ${ }^{3}$ In Paradise Lost, John Milton sequentially calls on "Winds,"

\footnotetext{
CONTACT Daniel Williams william1@fas.harvard.edu

'Latour, Pasteurization of France, 205; Coetzee, Dusklands, 118. References to Dusklands are hereafter cited parenthetically in the text.

${ }^{2}$ See Bogost, Alien Phenomenology, 38-45, 50-2.

${ }^{3}$ Psalm 98:4, 8.
} 
"Pines," "Birds," animals, and fish to "Witness if I be silent, Morn or Eeven,/To Hill, or Valley, Fountain, or fresh shade/Made vocal by my Song, and taught his praise." ${ }^{4}$ Recalling this animation of the nonhuman that both mutely precedes and vocally supplements poetry, William Wordsworth often calls on things to testify to his subjective states: "Witness, ye Solitudes! where I received/My earliest visitations, careless then/Of what was given me." These testimonies need not be conscripted solely for the purposes of praise. Many instances in the "poetry of witness" tradition call on the nonhuman to testify to acts of human violence. ${ }^{6}$ The title of Robert Frost's collection A Witness Tree (1942) speaks to how a tree at once marks out surveyed land and stands to evaluate events that take place around it; in ancient periods such trees gave shelter for the juridical assemblies designated by the older Teutonic roots of the word "thing."7

Can we then coherently imagine witnesses that are not human? Can an animal bear witness? Can a stone take the stand? In making witnesses of the nonhuman world, both scriptural-poetic catalogues and object-oriented litanies entail these somewhat comical questions, which are not without serious precedent. This essay brings together theoretical writing on objects, testimony, and trauma to develop the category of the "nonhuman witness," or what I will later call "attestants": bearers of a testimony that issues from the nonhuman world while reframing human projects. The portmanteau concept of the nonhuman witness, I will argue, helps disclose the narrative, ethical, and ecological work performed by peripheral objects in literature, showing the necessary entanglement of human and nonhuman concerns. J. M. Coetzee's first fictional work Dusklands (1974) will be the litmus test for this account, because its paired novellas represent acts and systems of human violence that have typically been held as more central than their narratives' insistent attention to the nonhuman world.

In the first section, I propose an alternative genealogy for recent "new materialisms" and ontologies of objecthood by bringing them into conversation with earlier literary-theoretical writings on testimony and trauma. New materialist accounts have advanced metaphysical arguments alongside methods for describing the imbricated networks of experimental science and reflections on the possibility of a "political ecology." 8 To their detractors, these accounts constitute selective readings of the philosophical canon, fashioning incoherent conceptual assemblages, disavowing while still engaging in anthropocentric description, and lapsing into commodity fetishism. ${ }^{9}$ I want to claim that the shared formal or rhetorical tactic of calling objects to witness, especially in a list or catalogue, may offer a more compelling ethical stance than any metaphysical position-taking. Object-oriented philosophies amplify the nonhuman drift of earlier writing on testimony and trauma, I argue, carrying to a logical conclusion the location of witness agency in a combination of animate and inanimate entities. The concept of the nonhuman witness brings together these two domains of inquiry and calls attention to the ethical stakes of recognizing the enmeshment of human and nonhuman entities, without treating humans with desultory unconcern or expressing "ardor for an unpeopled world." 10

\footnotetext{
${ }^{4}$ Paradise Lost, $127-8$.

${ }^{5}$ The Thirteen-Book Prelude, 316.

'See Wu and Forché, eds., Poetry of Witness; and Forché, ed., Against Forgetting.

${ }^{7}$ For "thing" as a legal gathering space see Latour, Politics of Nature, 54.

${ }^{8}$ Latour, Politics of Nature, and Bennett, Vibrant Matter, offer related discussions of "political ecology."

${ }^{9}$ For critiques of object-oriented ontology see Cole, "The Call of Things" and "Those Obscure Objects of Desire."

${ }^{10}$ Cohen, Stone, 9.
} 
In the second section, I consider how much space Coetzee's text expends on enumerated lists of objects akin to those above, particularly in its South African half ("The Narrative of Jacobus Coetzee"). Such object catalogues confer narrative heft and agency on groups of nonhuman witnesses. They weigh down the narrative while also providing material for a counter-narrative parody of its first-personal confession of colonial violence. Against a monologue obsessed with the subjective viewpoint, especially where violence is concerned, these object lists bear witness through an exhaustive, banal, mocking memorialization. They also recursively influence the form of the narrator's first-personal observations. To read for attestants complicates a view of Coetzee's early work as invested primarily in colonial subjectivity and its metaphysical underpinnings. ${ }^{11}$ Dusklands deserves to be read as much more than an exemplar of postmodern metafiction. In my account it stands, even now, as a commentary on what has been termed the "reality imperative" in South African literature and criticism, visible in the enduring aspirations to social mimesis and documentary witness; the appeals to "responsibility," "commitment," "engagement," "relevance," and "urgency"; and the "intimate enmity" between genres allied with fiction or fact. ${ }^{12}$

Nonhuman witnesses may be numerous, but they are also easily overlooked - so much descriptive disjecta in a narrative that represents brutality in visceral ways. In the third section, I address a problem for my reading - the objection that attending to objects does ethical and representational disservice to human victims - by outlining the more expansive temporal dimensions to which nonhuman witnesses give shape. Although attestants can be silenced and disposed of in the short term, in a longer temporal frame they acquire a shadowy, unforgettable status. Using another concept from the philosophical literature on trauma and testimony, I suggest that they acquire an "exigency" against forgetting. This power emerges, I propose, in the narrative's more serious (so to speak) mode of parody, where attestants do not proliferate in comic fashion but grimly persist beyond episodes of violence. This memorial perseverance of attestants is useful for thinking through the ecological concerns implied by the first half of Dusklands, “The Vietnam Project." This satire of the United States during the bellicose 1970s represents a conflict between human and nonhuman entities cognate with Coetzee's vision of the South African interior in the 1760s. But more crucially, it alludes to the long temporalities occasioned by ecological warfare. Linking these texts through their nonhuman worlds rather than the deranged subjectivities of their narrators (Eugene Dawn, a military propagandist; Jacobus Coetzee, a cruel frontiersman) means reading Dusklands not for its subversive or symptomatic responses to crises in South Africa and the United States at a particular historical moment, but for the more abiding details it hides in plain sight.

Through the nonhuman witness I thus aim to recover a durable power in Coetzee's strange early novel, despite its apparently backward-facing attitude, its alliance with the "ante-" and the "pre-" in a South African literary field that has developed through mostly "anti-" and "post-" constructions. ${ }^{13}$ At one level, reading for attestants uncovers an alertness to the nonhuman that holds for Coetzee's wider oeuvre and underlines his contribution,

\footnotetext{
${ }^{11}$ See Attwell, "'Labyrinth"'; Castillo, "The Mythic Punctum"; and Jolly, "The Gun as Copula."

${ }^{12}$ The term "reality imperative" I draw from De Kock, "Splice," 92; and "intimate enmity" from Twidle, "Literary Non-Fiction," 18. For classic statements and later revisions of these concepts see Ndebele, "Redefining Relevance"; Mphahlele, "African Writers and Commitment"; Coetzee, "The Novel Today"; Bethlehem, "'A Primary Need as Strong as Hunger"'; De Kock, "Splice"; and Twidle, "Literary Non-Fiction."

${ }^{13}$ On temporal continuity and disjunction in South African writing, and the "post-" and "anti-" in relation to apartheid, see De Kock, "Freedom on a Frontier?"
} 
however elliptical, to the strain of South African literature that is sometimes described as a "literature of witness." At another level, the ethics I elicit from Dusklands extends the temporal frame of this testimonial power to include an ecological domain, with its nonhuman claimants and environments, that may have more lasting importance than the transient political constellations usually adduced in historicist readings of Coetzee.

\section{Things, witnesses, attestants}

There are concrete precedents for the notion of nonhuman testimony. The numerous examples of animals and insects being summonsed, charged, and tried in Europe from the late Middle Ages through the nineteenth century remain a riddling historical-legal phenomenon. ${ }^{14}$ Until the mid-nineteenth century, the English law of "deodand" (recently invoked as an exemplar for new materialism) held that objects that caused the death of an adult person were to be rendered up to the sovereign, as though the mortal power of things gave them a guilty agency. ${ }^{15}$ Also in the nineteenth century, the phrase "res ipsa loquitur" ("the thing speaks for itself") entered English law as a doctrine of evidence "creat[ing] a permissible inference of negligence" where one could "only show that an injurious event occurred." 16 Legal standing can be accorded to trees, forests, rivers, and lakes, and when environmentalists write to advocate for their protection they often use the language of testimony and are subsequently anointed as nature's "witnesses." 17 These cases all concede some degree of agency to the nonhuman world and recognize that agency in legal contexts. In this section, I pivot from such figurative invocations to develop the idea of the nonhuman witness in a more speculative direction. First, I bring together several positions on the nonhuman to give theoretical shape to attestants as distributions of nonhuman beings or presences. I then summarize precursor debates about witnessing and trauma, highlighting their shared tendency to use nonhuman materiality to express certain paradoxical facts about bearing witness.

A major axis of the renovation of things puts forward a metaphysical program "object-oriented ontology" or "speculative realism" - that rejects the givens of human cognition, along with a tradition of philosophy that purportedly "grants no independent reality to the things in the absence of every human witness." 18 Quentin Meillassoux's term "correlationism" names this assumption that the contours of the world are established essentially in relation to human subjects, against which objects are seen as retreating from access, existing prior to their relations with other objects, and communicating with other entities only partially. ${ }^{19}$ For Graham Harman "the world is packed with individual substances that are limited, plural, have an inner core that endures despite changes on the surface," and that communicate by "emitting surfaces that somehow refer to the depths from which they emanate" through a "proximity without fusion." 20

\footnotetext{
${ }^{14}$ See Cohen, "Law, Folklore and Animal Lore"; and Dinzelbacher, "Animal Trials."

${ }^{15}$ See Pietz, "Death of the Deodand"; and Bennett, Vibrant Matter, 8-10 (on "legal actants").

${ }^{16}$ Webb, "The Law of Falling Objects," 1066.

${ }^{17}$ See Stone, Should Trees Have Standing? A founding text of ecocritical witness is Testimony (Trimble and Williams, comp.); see also Lear, Rachel Carson: Witness for Nature. For an overview of the "trope of speaking nature" in ecocriticism, critiqued as "an essentially colonizing move" (53), see Gilcrest, Greening the Lyre, 37-60.

${ }^{18} \mathrm{Harman}$, "Aesthetics as First Philosophy," 29. Generally brought together under these headings are the works of Harman, Quentin Meillassoux, lain Hamilton Grant, and Ray Brassier. For a cogent overview see Shaviro, Universe of Things.

${ }^{19}$ Meillassoux, After Finitude, 5; see 1-27. For a systematic rejection see Golumbia, '"Correlationism."'

${ }^{20}$ Harman, "Aesthetics," 23-4.
} 
By contrast, projects in political theory that often attract the moniker of "new materialism" insist on primary (and less mystical) relations and entanglements of animate and inanimate matter. What Jane Bennett calls "thing-power materialism" showcases the "recalcitrance or moment of vitality" in matter and recognizes the "agential powers of natural and artifactual things." 21 This view of agency as "distributed" owes much to Bruno Latour's Actor-Network Theory (ANT), an account emerging from science studies that describes the mingling of human and nonhuman "actants" in heterogeneous assemblages (hybrids, networks, "imbroglios") that in turn reimagine abstract, "homogeneous totalities" (nature, society, discourse) as open-ended collections of the elements of which they are composed. ${ }^{22}$ There are notable precursors and extensions of this work in the domains of literature and ecocriticism. ${ }^{23}$ Whether these theories see the nonhuman as receding from or forming productive entanglements with human actors, their rhetorical efficacy relies on the apparent paradox of investing nonhuman entities with animacy or communicative power. Latour frequently describes science as the work of making things talk, and scientists as "representatives" who utter "what the things would have said on their own, had they only been able to speak." 24

The formal or rhetorical energy of things speaking, interacting, and witnessing does real work in these accounts. I now want to point out how such paradoxes pick up on similar conundrums in an earlier philosophical literature on testimony, where things are called to speak because humans cannot or will not. Language and experience appear in these accounts as contiguous, fundamentally at odds, and witnessing is deemed impossible because (it is claimed) one cannot have and narrate an experience in the same moment. If witnessing is to be achieved, it can only be through some paradoxical collapse of testimonial conditions, and this tends to mean that paradigmatic witnesses are least capable of rendering their experience. The most credible witnesses of extreme suffering would be the dead, or beings similarly lacking subjectivity or humanity; ideal testimony seems to issue from the limit conditions of human life.

Take Jacques Derrida's short text Demeure, which engages with Maurice Blanchot's even shorter text The Instant of My Death. Blanchot's text recalls his experience of a mock execution by firing squad. ${ }^{25}$ Derrida's extensive close reading mines the paradoxes of this reported brush with death, its proxy testimonial structure and temporal disjunctions. In "presuppos[ing] the instance of the instant that, at that very instant, however, it destroys," testimony generates an unbridgeable gap between momentary presence and experiential duration, impossibly true witness and the time-lag testimony of survival. ${ }^{26}$ Blanchot's text includes a strange detail that Derrida cannot seem to read. "Even the bloated horses," Blanchot writes, "on the road, in the fields, attested [attestaient] to a war that had gone on." ${ }^{27}$ Derrida

\footnotetext{
${ }^{21}$ Bennett, "The Force of Things," 348, 349. See also Vibrant Matter and "Systems and Things."

22Latour, We Have Never Been Modern, 2, 126. For developing statements on ANT see also Politics of Nature and Reassembling the Social. Bennett, "Force of Things," 354-6, discusses "thing-power" in relation to Latour's "actancy" and "agency as a continuum" (355).

${ }^{23}$ See Brown, "Thing Theory" and A Sense of Things; Freedgood, The Ideas in Things; Morton, Ecology Without Nature and "An Object-Oriented Defense of Poetry."

${ }^{24}$ We Have Never Been Modern, 142. Cole exposes the idealist elements and mystical origins of this"convenient fiction [...] enabling the philosopher to hear the call of things and to speak to and for them, despite the new rule that we cannot think of objects as being-for-us and must reject older philosophies smacking of 'presence' and traditional ontology or ontotheology" ("The Call of Things," 107; see 111-13 for a critique of the trope of talking things).

${ }^{25}$ Derrida, Demeure, $51-2$.

${ }^{26}$ lbid., 32.

${ }^{27}$ Blanchot, Instant, 7.
} 
disdainfully observes that "a thing or an animal, a fortiori, a body could never attest to anything, even if it does attest, in the loose sense of being a clue or evidence." 28 Jean-François Lyotard similarly dismisses the animal in a related assessment of the problem of witness authority in the Nazi death camps. Defining "a wrong [tort]" as "a damage [dommage] accompanied by the loss of the means to prove the damage," specifically in a juridical setting, Lyotard argues that the animal is the "paradigm of the victim" because victims are stripped of the "means to prove" wrongs qua damages. ${ }^{29}$ The animal is constitutively "deprived of the possibility of bearing witness according to the human rules for establishing damages, and as a consequence, every damage [dommage] is like a wrong [tort] and turns it into a victim ipso facto." 30

Finally, for Giorgio Agamben the best witness is likewise the survivor - or superstes, the one who lives through and beyond, one of two distinct Latin words for witness. ${ }^{31}$ Those who have survived the most, so to speak, are least capable of putting their experience into language. Agamben meditates, via writers like Primo Levi, Jean Améry, and Elie Wiesel, on those in the concentration camps who lost the qualities that made them human. Levi calls them "the drowned" and sees them as "the complete witnesses, the ones whose deposition would have a general significance." ${ }^{2}$ For Agamben, they are paradoxical figures, "the human that cannot be told apart from the inhuman," bearers of a "language of testimony" insofar as it "is a language that no longer signifies and that, in not signifying, advances into what is without language." ${ }^{33}$ Agamben's recounting of the camp literature discovers a range of nonhuman figures for the living dead: donkeys, camels, trinkets, and dolls. ${ }^{34}$ In these bodies that persist in living - hence "remnants" - Agamben finds the evacuation of perception and language that defines witnessing as a limit concept. "That precisely this inhuman impossibility of seeing is what calls and addresses the human, the apostrophe from which human beings cannot turn away - this and nothing else is testimony." ${ }^{35}$

Even recuperations of testimony in literary and trauma theory that do not take such radical positions still anchor the ethical imperative of witnessing in material substance. Carolyn Forché describes the "poetry of witness" as "a mode of reading rather than of writing, of readerly encounter with the literature of that-which-happened, and its mode is evidentiary rather than representational - as evidentiary, in fact, as spilled blood." ${ }^{36}$ Cathy Caruth similarly describes trauma in bodily terms, as "not only [...] the enigma of a human agent's repeated and unknowing acts but also as the enigma of the otherness of a human voice that cries out from the wound." 37 By blurring concepts (witness and evidence) that have a separate function in modern legal systems, Forché at once reduces the poetry of witness to legal reportage and seems to admit that it has a shadowy analogue (call it the "poetry of evidence"). Caruth likewise turns evidence of damage into a witness that curiously speaks in human language, even though the other is nonhuman (a tree, in her example from Torquato Tasso's Gerusalemme Liberata).

\footnotetext{
${ }^{28}$ Derrida, Demeure, $80-1$.

${ }^{29}$ Lyotard, Differend, 5, 28, 8.

${ }^{30}$ Ibid., 28.

${ }^{31}$ Agamben, Remnants of Auschwitz, 17.

${ }^{32}$ Quoted in ibid., 33.

${ }^{33}$ Ibid., 82, 39.

${ }^{34}$ Ibid., 44, 51.

35Ibid., 54.

${ }^{36}$ Poetry of Witness, 21.

${ }^{37}$ Unclaimed Experience, 3.
} 
Blood, wounds, weapons: this is the stuff of circumstantial evidence, the Anglo-American legal concept that comes to supplement, often to challenge direct evidence or witness testimony from the eighteenth century forward, and that has historically acquired a voice in the figurative expression that circumstances "cannot lie." 38 The shaping force of the nonhuman persists in literary settings, where "witness literature" has come to define ethical or political engagement as such. When Nadine Gordimer joins other writers and Nobel laureates in discussing these matters, she cites one dictionary sense of "witness": "Attestation of a fact, event, or statement." ${ }^{39}$ Although this formula is notably impersonal, Gordimer uses it in ways that accord with the legal senses of persons testifying in speech or writing, by signature or oath, of what was seen or heard in their presence. ${ }^{40}$ What is elided, as in Derrida's hesitation, is the witness as that which "furnishes evidence or proof of the thing or fact mentioned; an evidential mark or sign, a token." ${ }^{11}$ The word "witness" includes the speech or signification of human and nonhuman entities.

There is thus always a shadow sense in which the witness either takes on a nonhuman form or draws its conceptual force from a zone that is not typically thought of as bearing vocal power or linguistic significance. The substratum of the nonhuman juts into these critiques that deem witnessing impossible because human subjectivity as commonly understood cannot adequately satisfy what testimony must convey: bodily experience anterior to or beyond language (Agamben); the temporal instant of death (Derrida); non-paradoxical modes of reference (Lyotard). These accounts tacitly include the concept of the nonhuman witness, whether in paradoxical (inhuman, aphasic, desubjectified) figures, or in images of evidentiary materiality. Conversely, the problem of testimony also edges into object-oriented accounts that, seeing "correlationism" as revealing reality only by way of human observers, try to undercut that position through the conundrum of the "un-witnessed." 4

Bringing these accounts together, and playing on Latour's term "actants," I call nonhuman witnesses "attestants" to get at the sense of an ensemble bridging human and nonhuman worlds in a testimonial sense. This concept takes literally the legal-bureaucratic figures by which Latour accords nonhumans a role and voice in a renovated collective. ${ }^{43}$ In the next section, I position Coetzee's early work as an antecedent to the material turn while pointing out that his deployment of the nonhuman witness has a vital ethical function. To describe attestants is to consider the potential ethical relations and modifications among entities in ways that remain agnostic about the metaphysics of objects. The concept affords the possibility of latent or mute witnesses that withdraw from access, as well as witnesses that are vocal and relational, but it maintains that such testimonies are finally referred to human recognition even if they address nonhuman concerns.

\section{The nonhuman frontier}

In examining Coetzee's early work for attestants, this section is designed as a recovery project. It tracks witness positions without glibly following the familiar hierarchy of colonial

${ }^{38} \mathrm{On}$ this phrase in Anglo-American law, and the rise of circumstantial evidence, see Shapiro, Historical Perspectives, $200-41$. ${ }^{39} O E D$, "witness, n.," def. 2.a, quoted in Gordimer, "Witness," 86.

${ }^{40} O E D$, "witness, n.," def. 3-6.

${ }^{41}$ lbid., def. 7a.

${ }^{42}$ Meillassoux, After Finitude, 19-21. Compare Harman, Prince of Networks, 122-34, 185-7.

${ }^{43}$ For example, the "parliament of things": Latour, We Have Never Been Modern, 142-5. Latour here also discusses the scientific"testimony of nonhumans" (22-4). 
aggressor, victimized indigene, and mute nonhuman background. It affords a flatter, more descriptive approach to Dusklands, demurring from the critical consensus that Coetzee necessarily satirizes the "propositional discourse of ontology and metaphysics," and resisting the assumption that his language clearly embodies "a reflexive and parodic critique of colonialism and imperialism." ${ }^{44}$ Provisionally bringing Coetzee into what Rita Felski has termed a "postcritical" space that questions the "presumptions of inherent rigor or intrinsic radicalism" in suspicious reading, the tenet of "skepticism as dogma," my account considers the tonal, affective, and potentially ethical aspects of the denotative catalogue. ${ }^{45}$ Dusklands co-opts several aspects of literary lists and catalogues: their tendency both to thwart narrative sequence and to court proto-narrative desire; their riot against order alongside their self-reflexive capacity to spotlight the border between fiction and fact. ${ }^{46}$ Coetzee's lists establish Dusklands as engaging in a mode of parody that opens a prosaic space alongside, rather than against, its original model. ${ }^{47}$ If we are alert to the nonhuman dimensions of witnessing encoded in such lists, we might hear an ethical address in the narrative's periodic deflection from human victims to material objects, an address that rivals the ethics of alterity some have sought in Coetzee's early allegorical or metafictional experiments. ${ }^{48}$

Dusklands is made up of two halves. Here I focus on the second, a narrative that Coetzee based on the travels of his distant ancestor, an eighteenth-century frontiersman and sheep farmer named Jacobus Coetzee, along the Western Cape of South Africa. The touchstone for this text is a historical testimonial (Coetzee calls it a "Deposition") sworn to by the real-life Jacobus about an uneventful trip beyond the so-called Great River in 1760, to hunt elephants. ${ }^{49}$ "The Narrative of Jacobus Coetzee" departs from historical fact to stage a fictionalized account of Jacobus's travels, set within a metafictional frame saturated by the tropes of colonial history and travel writing. Jacobus and his servants arrive in the land of the Namaqua tribe, but breaches of hospitality force them to flee the native village before decamping. Overnight Jacobus falls ill and in his feverish confusion is betrayed by his men, who hand him over to the Namaqua as a prisoner. On a second journey a year later, he undertakes a revenge expedition in which he executes his four traitorous servants and eradicates the Namaqua village in an astonishing display of brutality.

Across this bundle of historical, quasi-historical, fictional, and scholarly texts there are intentional mismatches: names, dates, and facts do not add up. Coetzee includes his own translation of the Deposition but shifts the order of events and adds details that have no parallel in the original. ${ }^{50} \mathrm{He}$ includes an "Afterword" by a fictional "S. J. Coetzee," a mock academic essay that reclaims Jacobus as a forerunner of Afrikaner nationalism and frequently glosses a simple description in the Narrative with baroque additions. Criticism

\footnotetext{
${ }^{44}$ Attwell, "'Labyrinth,"' 21, 7. For readings of Coetzee that analogize metaphysical (or psychological) and sociopolitical critique see Wood, "Dusklands and 'The Impregnable Stronghold of the Intellect"'; Gardiner, "Colonial Encounters"; Dovey, "Coetzee and His Critics"; Knox-Shaw, "A Metaphysics of Violence"; and Hamilton, "The Meaning of Suffering."

${ }^{45}$ Limits of Critique, 3, 9; for a defense of "postcritical reading" see 151-85.

${ }^{46}$ See Belknap, "The Literary List"; Von Contzen, "Limits of Narration"; Fludernik, "Descriptive Lists"; Richardson, "Modern Fiction"; and Alber, "Absurd Catalogues."

${ }^{47}$ For a discussion of these two senses of parody - "beside" and "against" (the song) - in literary tradition, see Agamben, Profanations, 38-41.

${ }^{48}$ For example, Attridge, "Ethical Modernism"; and Marais, "Ethics, Engagement, and Change."

${ }^{49}$ This document, in Dutch, is reproduced with facing translation in the edition on which Coetzee relies, The Journals of Jacobus Coetsé Jansz. (Mossop, ed.).

${ }^{50}$ Although Coetzee includes signature - an " $X$ " made before two "witnesses" (125) - he significantly removes the Dutch countersignature "Acordeert"/"Agrees with original" (Mossop, ed., Journals, 290-1). For an assessment of other omissions and additions see Attwell, "'Labyrinth,"' 16-17.
} 
on Dusklands tends to focus on the Narrative as a fantasy of colonial subjectivity, a representation (and critique) of various philosophies of history and origin myths predicated on individual subjectivity set against an inscrutable other. ${ }^{51}$ Yet the Afterword's abundant object catalogues, too often ignored, make visible an attention to the nonhuman periphery that also permeates the Narrative, rotating us out of Jacobus's monological viewpoint. Dusklands is a work "born of the archive," and hence partakes of the archive's materiality. ${ }^{52}$

Before examining these catalogues in detail, it is worth dwelling on the interior fantasy that has led critics to see Dusklands as both an "allegory of the colonial occupation and control of colonial space" and an "allegory of the quest for identity"; as a narrative that "selectively raids the traditions of Western philosophy so as to position them within the colonial situation, as a way of dramatizing the subject-constitution implied by the colonial encounter." ${ }^{33}$ Consider a moment of feverish insight where Jacobus describes the logic of the civilizing mission:

We cannot count the wild. The wild is one because it is boundless. We can count fig-trees, we can count sheep because the orchard and the farm are bounded. The essence of the orchard tree and farm sheep is number. Our commerce with the wild is a tireless enterprise of turning it into orchard and farm. When we cannot fence it and count it we reduce it to number by other means. Every wild creature I kill crosses the boundary between wilderness and number. I have presided over the becoming number of ten thousand creatures, omitting the innumerable insects that have expired beneath my feet. I am a hunter, a domesticator of the wilderness, a hero of enumeration. (80)

Counting divides up the undifferentiated unity of nature; the gesture is typical of Enlightenment projects that assisted colonial expansion, such as naturalist taxonomy. ${ }^{54}$ This reflection fits into a ranting sermon on the gun as a metaphysical demonstration of exteriority, reality, and otherness (79-81), and on weapons more generally as "extensions of the self" (79). It is an "argumentative list," a catalogue qua logical demonstration, with a looping syntax that only makes sense when quoted en bloc. ${ }^{55}$ The form of this reflection thus implies that the wilderness never disappears, that it remains stubbornly vibrant despite such heroic enumeration. At the limit, the unending ("tireless") project of counting, domesticating, and civilizing could be seen as actually constituted by the infinite wild over and against which it sets itself. Similarly, the Narrative's weird Emersonian image of Jacobus as "a spherical reflecting eye moving through the wilderness and ingesting it" is meant, he claims, to show that there is "[n] ot a stone, not a bush, not a wretched provident ant that is not comprehended in this travelling sphere" (79). But in the dual sense of "comprehend" (to include and understand), these singular items cannot but exceed his reach. Jacobus is paradoxically obsessed with both an infinite plenitude that stretches from "horizon to horizon" (79) and the construction of the same space as a "vacuum" (78) or terra nullius that is open to appropriation, coordinate mapping, and resource extraction. When Jacobus has fled captivity and is trekking back to his homestead, alone, he again indulges in numerical games that try to flee materiality even as they scrupulously pile it up: "To keep my mind fed I computed all the denominators I could think of," "the number of paces in three hundred

\footnotetext{
${ }^{51}$ For instance, Knox-Shaw, "A Metaphysics of Violence"; Gardiner, "Colonial Encounters"; Jolly, "The Gun as Copula”; Attridge, "Ethical Modernism"; Castillo, "The Mythic Punctum"; and Collingwood-Whittick, "Colonialist Myth."

${ }^{52}$ Wittenberg, "Towards an Archaeology of Dusklands," 74.

${ }^{53}$ Ashcroft, "Habitation," 37; Dovey, "Coetzee and His Critics," 22; Attwell, "'Labyrinth,"' 7.

${ }^{54}$ See Pratt, Imperial Eyes.

${ }^{55}$ See Fludernik, "Descriptive Lists," 310-12.
} 
miles" (99). Every attempt to establish identity and subjectivity, to count and draw boundaries, seems to be eclipsed by non-identity and objecthood.

At the narrative edges of these nervous monologues the nonhuman acquires a striking voice. When Jacobus meditates on his life as a "tamer of the wild" (77), he comes "face to face with the alien certainties of sun and stone," which he fantasizes as addressing him:

Behind this familiar red or grey exterior, spoke the stone from its stone heart to mine, this exterior jutting into every dimension inhabited by man, lies in ambush a black interior quite, quite strange to the world. Yet under the explorer's hammerblow this innocent interior transforms itself in a flash into a replete, confident, worldly image of that red or grey exterior. How then, asked the stone, can the hammerwielder who seeks to penetrate the heart of the universe be sure that there exist any interiors? (77-8)

This conceit, which alludes to Olive Schreiner's The Story of an African Farm (1883), assumes a congruence and channel of communication between human and nonhuman that it then undermines. ${ }^{56}$ Stones at first have hearts and voices, but are soon discovered, through Jacobus's ventriloquism, to retreat in an endless regress of surfaces and silences. These reflections are allusive in further directions, too. The oddity of stones talking recalls a refrain in $\mathrm{T}$. S. Eliot's The Waste Land: "Only/There is shadow under this red rock,/(Come in under the shadow of this red rock)." ${ }^{57}$ Jacobus's insistent attempts to exert control over the environing world by usurping its voice thus bring into view, at certain moments, more vocal nonhuman presences than he would generally acknowledge. In his deranged escape, he declares: "I love everything. I love the stones and the sand and the bushes and the sky and Klawer [his servant] and those others and every worm, every fly in the world. But God, don't let them love me. I don't like accomplices, God, I want to be alone" (95-6). But Jacobus interrupts his solitude by returning, as if by summons, to the beginning of his list: "the stones, I decided, so introverted, so occupied in quietly being, were after all my favorites" (96).

It is tempting to compare statements like this to Coetzee's later speech on receiving the Jerusalem Prize, in 1987, where the Afrikaner love of the nonhuman - of "what is least likely to respond to love: mountains and deserts, birds and animals and flowers" - is castigated for its corollary hatred of part of the human world.$^{58}$ Afrikaans literature is, in a phrase that acquires a new valence in this discussion, "a less than fully human literature." ${ }^{59}$ Yet a decade after Dusklands, in a review of Athol Fugard's notebooks, Coetzee suggests that his compatriot navigates the line between art and propaganda by "tak[ing] upon himself (following Sartre) the task of bearing witness. 'The truth [must] be told ... I must not bear false witness.' 'My life has been given its order: love the little gray bushes', by which he means, love the insignificant, the forgotten, the unloved." ${ }^{0}$ If this account of Fugard's "program of witness and love" sounds unexpectedly mocking, oddly aligning an activist liberal playwright with the landscape-loving Boers, it may be because both assume a unidirectional relation between subject and world. ${ }^{61}$ In Dusklands, to the contrary, the nonhuman world seems poised to offer its own responses or testimonies. Even within the first-personal tunnel that surveys

\footnotetext{
${ }^{56}$ Waldo asks Lyndall: "has it never seemed to you that the stones were talking with you? Sometimes [...] I lie under there with my sheep, and it seems that the stones are really speaking" (The Story of an African Farm, 49).

${ }^{57}$ Eliot, The Waste Land, I, II. 24-6.

${ }^{58}$ Doubling the Point, 97.

${ }^{59}$ lbid., 98.

${ }^{60}$ lbid., 370

${ }^{61}$ Ibid.
} 
the landscape down the barrel of a gun we glimpse a recalcitrant world of matter that has something else to say, however taciturn it remains.

Coetzee frames Jacobus as a pathological philosopher whose musings on his superior powers betray an anxiety about the resistance of, rather than an appropriative desire ("love") for the brute world. A final example sees him entertaining a fantasy of pure exteriority that takes enumeration to an absurd limit. Jacobus reflects on a species of beetle known to feign death:

You may pull his legs off one by one and he will not wince. [...] What passes through his mind during these last moments? [...] in a formal sense he is a true creature of Zeno. "Now I am only half-way dead. Now I am only three-fourths dead. Now I am only seven-eighths dead. The secret of my life regresses infinitely before your probing finger. You and I could spend eternity splitting fractions. If I keep still long enough you will go away. Now I am only fifteen-sixteenths dead." (96)

Jacobus claims to have taken a lesson from this beetle, sequestering himself in the "labyrinth of my self" when in captivity and disgrace, but his failure to mimic the life that "regresses infinitely" beneath the "probing finger" (96) only serves to underline a deeper disquiet about the nonhuman.

In the Afterword, this vision of a world that is apparently open to being killed, counted, domesticated, and interiorized takes on a more laconic form. Here objects are enumerated in lists that, in my account, can be read as adding witnesses to the record. Leaning on the tendency of lists to embody "a thingness of [their] own" - "as inherently nonnarrative elements, [to] constitute 'the Other' in a literary work" - Coetzee emphasizes what always populates the edge or background of histories and travel narratives, even when such accounts insist on the emptiness or unimportance of the landscapes they describe. ${ }^{62}$ The sheer profusion of objects in both Narrative and Afterword draws attention further away from Jacobus's solipsistic thoughts. Coetzee makes sure we know every possible commodity and object of trade, in lists that underline colonial rapacity and its extractive inequity: "honey, wax, ostrich feathers, elephant tusks, silver, gold, pearls, tortoiseshell, musk, civet, amber, pelts," to be exchanged for "tobacco, spiritous liquors, beads and other glass artifacts, metals, firearms and powder" (110). The Afterword lavishes comic attention on the contents of Jacobus's wagon:

His wagon contained: black, white and blue porcelain beads, tobacco, knives, looking-glasses, brass wire, three muskets, balls, a barrel of gunpowder, a bag of shot, flints, bars of lead and a bullet-mould, blankets, a saw, a spade, a hatchet, spikes, nails, ropes, canvas, a sail-needle, oxhide, yokes, halters, tar, pitch, grease, resin, linchpins, hooks, rings, a lantern, rice, biscuit, flour, brandy, three water-casks, a medicine chest, and many other things - civilization, in fact, in ovo. (118)

On the face of it we seem to have only "absurd lists of empirical data,"63 presented in a language where words themselves start to acquire the density and opacity of things. The grammar of the list, as it were, then leads us out of materiality into an abstract telos ("civilization"). Yet the nodes of this richly descriptive catalogue might link up to tell or supplement any number of narratives. It lists items to be consumed or used up; tools and technical achievements; models for producing future objects; utilitarian and luxury items;

\footnotetext{
${ }^{62}$ Von Contzen, "Limits of Narration," 244, 245.

${ }^{63}$ Dovey, "Coetzee and His Critics," 21.
} 
violence-bearing as well as life-giving things. Indeed, the only counted objects are agents of life ("water-casks") and death ("muskets").

With overtones of the "Ithaca" episode of James Joyce's Ulysses (1922), the Afterword even tries to list everything the expedition left behind. On one night alone, we have:

the ashes of the night fire, combustion complete [...]; faeces dotted in mounds over a broad area, herbivore in the open, carnivore behind rocks; urine stains with minute traces of copper salts; tea leaves; the leg-bones of a springbok; five inches of braided oxhide rope; tobacco ash; and a musket ball. The faeces dried in the course of the day. Rope and bones were eaten by a hyena on August 22. A storm on November 12 scattered all else. The musket ball was not there on 18 August 1933. (118-19)

These comically thorough details exhibit scientific precision, archaeological diligence, scatological jest, and historical or quasi-historical recording. Carrol Clarkson notes of such lists that "the planes of present appearance and historical past converge" in denomination, "in the remains of the name." ${ }^{64}$ David Attwell argues that they are instances of "aesthetic defamiliarization" wherein "reference is so obsessively emphasized that it loses its referential function, [...] draw[ing] attention to the subject-position informing the practice - the fragile imperial subject." ${ }^{\prime 5}$ Yet it is significant how insistently the name marks the vibrant presence of the nonhuman, how often the frantic attention to reference draws attention to objects more than subjects. Indeed, this passage's main point arguably concerns not human subjectivity but rather the material substrate that links referential persistence to historical remembrance: "These relicts, deposited over Southern Africa in two swathes, soon disappeared under sun, wind, rain, and the attentions of the insect kingdom, though their atomic constituents are still of course among us. Scripta manent" (119). It is significant that the apparent power of writing to sublimate matter into the form of immaterial endurance is juxtaposed with the more obvious power of weapons to convert matter otherwise: "Musket balls, those which found their mark and were subsequently cut out, those which found their mark more or less but were never recovered, [...] and those which found no mark, but struck the earth and embedded themselves or fell exhausted to its surface, memorialized their track on either side" (119). The wider point, though, is that these nonhuman things that endure or remain ("manent"), longer than any human agent or text, are with touching vanity described as written things ("scripta").

Jacobus's own fantasies of self-possession even fall into this sort of object catalogue: the colonizing, appropriating interior starts to mimic its object exterior. When he leaves the village, he demands his "things" - "My oxen. My horses. My guns. My men. My wagon" (91) - but on the way "back to civilization" property gives way to privation, grammatical and otherwise: "We have nothing, no wagon, no oxen, no horses, no guns, nothing but what we carry on our own backs" (91). When Jacobus and Klawer are "liv[ing] from the veld like Bushmen" (92), the nonhuman world becomes more appreciable as subjectivity's essential resource: "we lived adequately on roots and on nestlings which we baked in mud and ate a dozen at a time bones and all. I made witgatkoffie and enjoyed it. I cut myself a willow bow and with arrows tipped in giftbol spent the mornings lying in wait for animals coming to drink" (93). At key moments, Jacobus drifts off into choose-your-own-adventure reveries that supplement his travel account, twisting narrative movement into a looping object litany:

${ }^{64}$ Countervoices, 149. On the Afterword's style see Zimbler, Politics of Style, 46-8.

${ }^{65}$ "Coetzee's Estrangements," 238. 
Tranquilly I traced in my heart the forking paths of the endless inner adventure: the order to follow, the inner debate (resist? submit?), underlings rolling their eyeballs, words of moderation, calm, swift march, the hidden defile, the encampment, the gray-beard chieftain, the curious throng, words of greeting, firm tones, Peace! Tobacco!, demonstration of firearms, murmurs of awe, the vengeful wizard, the feast, glut, nightfall, murder foiled, dawn, farewell, trundling wheels, the order to follow, [...] these forking paths across that true wilderness without polity called the land of the Great Namaqua where everything, I was to find, was possible. (65-6)

The Narrative thus provides a register of adventures against inventories of objects. One side offers an internal plan of actions, the other an external list of things; one is fraught with contingency, the other inert with necessity; one is latent with colonialism's avenues of expansion, the other limited in its matter-of-factness. Both compete for narrative attention because both are witness to the same system. Coetzee switches between different styles of description and catalogue, some vaunting their significance and others coyly gesturing at hidden depths, some sympathetic and interior, others flat and merely documentary, but all carrying narrative potentiality.

What are the broader repercussions of reading Dusklands in this way? My account focuses on catalogues - bland lists, quasi-logical sequences, comic inventories - to complicate the critical posture that treats Coetzee's representations as exposing colonial psychohistory simply by means of reflexive metafiction. What have come to be called "symptomatic" or "paranoid" readings have often seemed warranted for Dusklands, in view of its two clearly paranoid protagonists (Jacobus Coetzee, Eugene Dawn) and its density of historical, theoretical, and philosophical allusion. ${ }^{66}$ Assessments of Coetzee's early career sometimes see his postmodern shuttling between historical fictions and placeless allegories as a way of deflecting the presentness of (for the most part) South African problems. ${ }^{67}$ On the other hand, Coetzee's later work can lead to the assumption that these early representations of paranoia and violence must be satirical, casting an incontrovertible negative judgment on Jacobus (and his violent twin, Dawn, in the other half of Dusklands) ${ }^{68}$ Where allusions to Descartes, Hegel, Emerson, Nietzsche, Freud, Sartre, and Lacan have previously been tracked like so many nimble gemsbok, here the colonial manifest occupies the view. The "lumpish tedium" (77) of conquest becomes an intermittent driver of style: Dusklands seems to delight in measuring the actual weight and heft of objects. ${ }^{69}$ Focusing on nonhuman entities and environs, it provides witnesses to scenes where the degradation of human beings becomes all the more shocking for its descriptive neutrality and low affect. Such a claim parallels recent models of interpretation that have attended more to descriptive surfaces than symptomatic depths: Heather Love's "flat" reading of Sethe's infanticide in Toni Morrison's Beloved, for

\footnotetext{
${ }^{66}$ For a reflection on these terms in contemporary criticism see Felski, Limits of Critique, 14-51. Alongside Attwell,"'Labyrinth,"' see Head, J. M. Coetzee, 28-48, and Poyner, J. M. Coetzee and the Paradox of Postcolonial Authorship, 15-31. Language and style do, in some exceptions, trump diagnosis: see Clarkson, Countervoices, 141-4, 146-51; and Zimbler, Politics of Style, 25-55.

${ }^{67}$ For early statements see Vaughan, "Literature and Politics"; and Watson, "Colonialism." For Attwell, Coetzee's "fictive displacement" and "imaginative relocation" embody "a struggle both to speak at all and to keep the country at arm's length" ("Coetzee's Estrangements," 233).

68"That Coetzee's novels interrogate colonialism's discursive power is indisputable," assumes Parry ("Speech and Silence," 150). Attwell sees the text as satirizing the "scientific discourses" of Enlightenment, such as "mythography," the "exploratory narrative, colonial adventure writing, landscape and manners-and-custom description, and frontier or pioneer history" (“'Labyrinth,"'11).

${ }^{69}$ Coetzee is elsewhere alert to how the colonial enterprise was literally freighted with baggage that left a material deposit in the language: in Boyhood, he describes Afrikaans as "weighed down with idioms that are supposed to come from the volksmond but seem to come only from the Great Trek, lumpish, nonsensical idioms about wagons and cattle and cattle-harness" (81).
} 
example, where one version of the events "suggests the possibility of an alternative ethics, one grounded in documentation and description" that "draws attention to what is irrecuperable in the historical record."70

Extending the narrative horizon to include the nonhuman can further serve as a commentary on readings of the "real" in South African literature and criticism that turn on factual relevance or authenticity. As Leon de Kock argues, South African writing has been invested since colonial times in a "documentary turn" that relies on the "authority of the witnessed event, the natural or 'scientific' phenomenon, or the recorded fact," thereby "passing off a representational mode as an article of truth." ${ }^{71}$ Coetzee has typically been taken to resist these gestures through his "metafictional" and "postmodern attitudes to history," his "refusal to treat history as an a priori system."72 He seems to strain against the prominent social history of 1970s South Africa, the "history from below" movement with its attention to material reality. ${ }^{73}$ Yet it is hard to see Dusklands as merely bartering concrete reference for metafictional reflexivity, because even as it flaunts its fictional apparatus it remains fanatically tethered to the real: its maps, coordinates, distances, names, dates, and documents usually have referents, and it would not be impossible to input these coordinates and reconstruct the journey. ${ }^{74}$

The tonal variation and allusive richness of Coetzee's object catalogues, along with the temporal bridging of twentieth-century America and eighteenth-century South Africa, suggest that Dusklands is not simply a parody of material-oriented history, an "anti-documentary." 75 Coetzee maintains the vibrancy and heterogeneity of the things he lists. They are not resorbed into the historical Afterword that instances them, but sit obdurately in the textual record, as if awaiting a longer view. In this way Dusklands can be seen to approach what Love calls an "objectivity [that] also makes legible material processes of dehumanization." 76 What I have termed attestants embody the text's latent ethics, giving an uncannily material character to the Narrative's concluding thought, that Jacobus "can attain and inhabit a point of view from which [...] [he] can be seen to be superfluous" - that, in a perfectly literal sense, he has "other things to think about" (107).

\section{"Scripta manent": ecology and exigency}

If Coetzee's work both foreshadows and tacitly upends the methodological litanies with which I began, this opens out a yet broader terrain of analysis. Theorists of things may hold different positions but they seem to agree that their listing exercises are de facto acts of resistance to a sort of metaphysical tyranny: the "repeated sorcerer's chant of the multitude of things that resist any unified empire"; the catalogue that sees "objects in relation apart from us" in order "to release objects like ghosts from the prison of human experience."77

\footnotetext{
${ }^{70}$ Love, "Close but not Deep," 375, 387.

${ }^{71}$ De Kock, "Splice," $85,88$.

${ }^{72}$ Green, "Social History," 132; Marais, "Ethics, Engagement, and Change," 160.

${ }^{73}$ Green, "Social History," 125; De Kock, "Splice," 92-3. For a more general statement see Attwell, "The Problem of History."

${ }^{74}$ Easton suggests that Coetzee follows the more porous fact/fiction discourse of eighteenth-century writing ("Question of History," 15). Zimbler, Politics of Style, 35-45, offers an engaging contrast between Coetzee's "pared-down description [...] oriented, in its very grammar, towards the world" (42) and Alex La Guma's similar inventories that, in Coetzee's critical assessment, "focus [...] attention on the epiphenomena of a bad reality" (55) and catalogue the real as a way of fleeing it. ${ }^{75}$ Knox-Shaw, "Metaphysics of Violence," 66.

${ }^{76}$ Love, "Close but not Deep," 386.

${ }^{77}$ Harman, Prince of Networks, 102; Bogost, Alien Phenomenology, 65.
} 
Latour, Harman, Bennett and others assume that lists indulge in the non-hierarchical order of what Theodor Adorno theorizes as "parataxis," where fragments of language become "artificial disturbances that evade the logical hierarchy of a subordinating syntax," resisting the wider domination of political and philosophical synthesis. ${ }^{78}$

On one level, Coetzee's lists could be read in a similar way, as perversely trying to undercut the colonial project by placing its material requirements and by-products on a par with its human participants: hunters, servants, oxen, rolls of copper, a tinderbox, a bleached tortoise shell, "the date 1685 carved on the rocks" (63), the leavings of the gun, "a mountain of skin, bones, inedible gristle, and excrement" (79), the village "slaughtering pole" (72). ${ }^{79}$ In the Afterword, Coetzee has his scholarly narrator catalogue all the items that "contributed to [...] survival" (120) on Jacobus's journey by means of a scientific taxonomy of flora, small game, and insects, along with their respective sizes, weights, Latin names, and historical genealogies. ${ }^{80}$

Yet on another level, as this association of Coetzee's object catalogues with colonial violence suggests, the stringing together of attestants does more than disclose networks of human and object actors who share "metaphysical equality" ${ }^{81}$ Unlike the lists of speculative realism, Coetzee's parodic catalogues play a role at once ludic and ethical. Nonhuman witnesses are both mute presences and ethically over-generative forces. They are at once forgotten historical data and clues to what Walter Benjamin called the "the unforgettable": "the life that is not to be forgotten, even though it has no monument or memorial, or perhaps even any testimony," the "life [that] remains unforgettable even though without form or vessel." 22 Glossing Benjamin's idea, Agamben proposes that "the unforgettable is articulated only in parody" ${ }^{\prime 3}$ In a mode of serious parody, so to speak, the attestants that occupy Coetzee's catalogues amplify the vibrancy of the historical record. In their absurd, parodic form they enlarge the terrain of legal and ethical consideration and materialize the object world that is pressed into the service of colonial expansion. The Afterword's obsessive details undercut the logic whereby to enumerate is to master. They mock the cartographic coordinates and taxonomic categories central to the colonial project, offering a counter to Dawn's earlier self-defeating fantasy of "attacking the co-ordinates themselves" (28).

Witness to atrocities pressed into the space of days and weeks, Coetzee's attestants further operate as markers of the environmental "slow violence," in Rob Nixon's term, that continues to accrue around them at scales that eclipse lives and generations. ${ }^{84}$ The inhuman durability of attestants undermines what Nixon labels the "social authority of witness," limiting the scope of literary description or environmentalist writer-activism and "conjur[ing] spans that transient humans cannot witness and yet are called upon, anxiously, to narrate." ${ }^{85}$ Coetzee's nonhuman witnesses press at the edges of this Narrative and rotate us away from sympathizing with the violent interior viewpoint of colonialism, but they also remain stubbornly

\footnotetext{
${ }^{78}$ Adorno, "Parataxis," 131.

${ }^{79} 1685$, as the Afterword notes, is the date of Van der Stel's expedition (112). Latour offers an account of guns as actants together with those who use them in Pandora's Hope, 174-80.

${ }^{80}$ Describing his historical and anthropological reading for Dusklands, Coetzee mentions "makeshift grammars put together by missionaries" and "word lists compiled by seventeenth-century seafarers" (Doubling the Point, 52).

${ }^{81}$ Harman, Prince of Networks, 16.

82"Dostoyevsky's The Idiot," 80. I owe this concept to Agamben, Time That Remains, 39-40.

${ }^{83}$ Agamben, Profanations, 35.

${ }^{84}$ Slow Violence, $1-44$.

${ }^{85}$ lbid., 16; Cohen, Stone, 85.
} 
in service of an exterior viewpoint epitomized by material persistence in the environment - of stones, musket balls, fossils, and soil silicates.

If the nonhuman world might be the locus of an ecological reading of Dusklands, we need to recognize that supposing such a viewpoint risks eliding the cruelties predicated on the double genitive in "The Narrative of Jacobus Coetzee," which makes the text's violence both about and belonging to him alone. One might object that trying to pay attention to the Afterword's parody omits the violence perpetrated against animal and human life: surely this is to remain blind to the catalogue of colonial violence? Both halves of Dusklands do gleefully engage in representations of extermination, rendered in language that is often "tasteless, chummily explicit." 86 Of the "Bushmen," Jacobus scoffs that it "is only when you hunt them as you hunt jackals that you can really clear a stretch of country" (59). This framing of living creatures as unwanted entities, as vermin, has of course formed the pretext for operations of annihilation in the South African setting. ${ }^{87}$ The Narrative has recourse to the notorious language of "cleansing" for driving people out of lands - "we swept this district" (59) - and explicitly stages a hunt for "Bushmen" at dawn, with the "Hottentots" "at first light" "beating up one side of the hills," and men on horseback waiting to pick off their targets (59). Later, on his revenge expedition, Jacobus orders his men to "collect all the cattle, wipe the village off the face of the earth" (102), in an instance of the "unsettling overlap between the idiom of punitive righteousness and that of ethnic opprobrium" that has its touchstone in the divine threat of Genesis: "I will destroy man whom I have created from the face of the earth." ${ }^{8}$ In "The Vietnam Report," Dawn's research likewise speaks of the "non-significant dead" who merely increase the body count (23): "Atrocity charges are empty when they cannot be proved. 95\% of the villages we wiped off the map were never on it" (22).

The difficulty with such representations is that their language has clearly been deployed with historical and figurative accuracy: satire and parody are tethered to sober fact. As Nigel Penn has revealed, the history of the frontier conflicts of the Western Cape in this period is rife with instances of rapacious "unofficial commandos" in which colonists sought to purloin livestock or punish natives for its theft. ${ }^{89}$ One such raid precipitated the frontier war of 1739 and follows the route of the later journey (factual and fictional) of Jacobus. Until another frontier conflict in 1770, as "the area of land available to the colonists increased tenfold," there were numerous commandos whose documentation, "in the form of reports to the landdrost, were not so much concerned with recording details of the social life of the Khoisan as they were with providing a simple score sheet of people killed per day." 90 This history is accompanied by a figurative dehumanization, already evinced in the language of "cleansing," which connects to a longer tradition of degrading epithets used to describe native peoples in European literary and travel narratives, often as a pretext to xenophobic violence. ${ }^{91}$ Coetzee's later work shows him amply aware of these trends, and he alludes to them in various ways in Dusklands. ${ }^{92}$

\footnotetext{
${ }^{86}$ Castillo, "The Mythic Punctum," 1117.

${ }^{87}$ On jackals as vermin in South African history see Beinart, Rise of Conservation, 195-234.

${ }^{88}$ Rawson, God, Gulliver, and Genocide, 238; Genesis 6:7.

${ }^{89}$ Forgotten Frontier, 35.

${ }^{90}$ Ibid., 81, 88.

${ }^{91}$ Ibid., 102. For the analogies used to frame Khoikhoi and San see Voss, "The Image of the Bushman." On the afterlife of such tropes see Rawson, God, Gulliver, and Genocide, 92-182, 209-24.

${ }^{92}$ For example, the essay on Sarah Gertrude Millin's work and the figures of "Blood, Taint, Flaw, Degeneration," in White Writing, 141-67.
} 
I suggest that Coetzee's attention to the nonhuman, to animals and objects, does help us call attention to these moves of analogical devaluation in language and literal degradation by means of violence. It is a way to stall, by being vigilant about its linguistic gestures, Jacobus's dismissal of the servants he murders as "nonentities swept away on the tide of history", to be "picked by the vultures, and [...] forgotten in a week" $(101,102)$. It pushes against the way that Jacobus's reprisal expedition is excused by its spiritual and aesthetic frame - as a paean to the Greek notion of "beautiful death"; a "tableau" that we are encouraged to fill in and could supplement with "the classic writers on warfare" (100); and a demonstration of the "great system of dividends and penalties" seen in "Our Lord's observation on the fall of the sparrow: the sparrow is cheap but he is not forgotten" (101). It resists the symptomatic construal of a "silent other, who exists [...] principally as a background on which force is exerted" - whose presence is necessarily "effaced," "buried in the conventions of scholarly writing," "hidden in eyewitness accounts" - in preference for a more descriptive recognition of the "inhuman counterhistory denied by the depersonalized colonialist narrative." 93

Even when inflected by the nationalist fervor of the Afterword, dated to coincide with the rise of the apartheid state in 1948, object catalogues undercut the description of the Narrative as one in which brutal expeditions, "full of incident though they are, are nevertheless somewhat of an historical irrelevance" (120-1). This corrective does need to be kept in proportion. These features of the represented world of Dusklands are irrelevant and forgotten at some level. What attestants promise is a different modality, whereby the things that have been deemed worthless, too inconsequential to document other than in dry lists, take on what Agamben terms "exigency": they demand not to be forgotten, even when they are. ${ }^{94}$ Attestants shelter the unforgettable in every concrete forgetting: their ethical power, latent and belated, demands our interpretive attention and imagination.

It is this sense of exigency, of latent remaining, that links the Narrative both to its American twin and to environmental issues closer at hand. Eugene Dawn takes up Jacobus's paradox of existential confirmation in the context of the Vietnam War, to which he contributes as a cultural propagandist: "Our nightmare was that since whatever we reached for slipped like smoke through our fingers, we did not exist; that since whatever we embraced wilted, we were all that existed" (17). As in Jacobus's raids, this metaphysical war is carried on with "the gun and its metaphors, the only copulas we knew of between ourselves and our objects" (17). But to these traditional "probes of reality" (17) are added different weapons, to which Jacobus anachronistically alludes in noting that the gun is ineffective against plants and trees where "a flame-throwing device" (79), not invented circa 1760, might work. Dawn reflects on how incendiary weapons have still not resulted in victory or confirmation of existence: "We bathed them in seas of fire [...] but when the fire died they were only ash" (17). He goes further and offers almost a manifesto for "slow violence." Dawn acknowledges that the United States has "attacked the earth, explicitly in the defoliation of crops and jungle, implicitly in aleatoric shelling and bombing," and seeks to generalize this scattershot approach - every misguided bomb is still "heard by human ears, wears down hope in a human heart" - by "spray techniques" (29). Spraying "will always be more effective than high explosive in a campaign against the earth," and Dawn advocates the use of "a soil poison, a dramatic poison which [...], washed into the soil, attacks the bonds in dark silicates and

\footnotetext{
${ }^{93}$ Castillo, "The Mythic Punctum,"1111-12.

${ }^{94}$ See Time That Remains, 39-40; and Profanations, 35.
} 
deposits a topskin of gray ashy grit" (29). Such weapons outlast official conflicts, carrying on "unofficial hostilities in the cellular domain" with "the untidy, attritional lethality that moves through the tissue, blood, and bones of combatants and noncombatants alike." 95 Coetzee appends to Dusklands, one assumes with irony, an epigraph from Herman Kahn's notorious Can We Win in Vietnam? (1968), which justified the use of napalm; an apposite parallel allusion would have been John Lewallen's Ecology of Devastation: Indochina (1971), since the warfare here is as often ecological as "conventional." ${ }^{6}$

Taking up Jacobus's perversion of sympathetic imagination, Dawn sits in his own object fortress - "in the depths of the Harry Truman Library, walled round with earth, steel, concrete, and mile after mile of compressed paper" - and "send[s] forth this winged dream of assault upon the mothering earth herself" (28). Where Jacobus's revenge took place along a specified path against known entities, Dawn's kindred "exploring temperament" (31) seeks expression in random outbursts against unseen targets, even as his subjectivity is haunted by the records, statistics, and photographs he carries. "The Vietnam Project," with its introverted account of a paranoid sadist on the brink of mental collapse, thus reveals at the margins and through a macabre voice less a comic catalogue than an object environment that steadily resists Dawn's own aims of inventory and violence. It is as though the witnesses that will outlast Dawn oppose to his celebration of violence an orientation more attuned to the latent and enduring - to what Derrida captures in the term "demeure" (an abode, a place of remaining) and Agamben in the idea of "remnants." To attend to the problem of slow violence in Dusklands is not to ignore historical human casualties but to place them in the context of a longer array of human and nonhuman damages, to read with grim literalness Dawn's boast that he "speak[s] with the voice of things to come" (29).

\section{Conclusion}

The two halves of Dusklands give us a "Narrative" and a "Project," the first growing out of a "deposition" and the second centered in a "report." Buried in all this documentary activity and solipsistic validation, I have been arguing, is an ensemble of objects, materials, and relations that acquire a narrative agency of their own. Their "thing-power" (to use Bennett's term) can be seen to have an ethical function in widening the network of witnesses to acts of violence, and an ecological role in opposing endurance, exigency, and latency to the long shadow of slow violence. This deployment of things to describe wider horizons surrounding the human becomes a persistent, if less explicit feature of Coetzee's later work, whether it discloses the possibility of other realms and zones of being or opens out the complex layering of historical event and psychic life.

In the Heart of the Country (1977), for example, gives vent to the "stony monologue" of its narrator Madga, who "hear[s] the cascade of thousands of grains of sand," "smell[s] the iron exhalation of rocks in the sun," and "ache[s] to abdicate the throne of consciousness

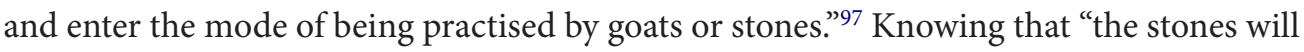
be here when I have crumbled away," she nevertheless consoles herself with the ontological divide between her language-bound self and "the stones and bushes of the veld," which "hum with life [...] because I am here to set them vibrating with their own variety of material

\footnotetext{
${ }^{95}$ Nixon, Slow Violence, 200.

${ }^{96}$ On Lewallen see ibid., 211.

${ }^{97}$ In the Heart of the Country, 12, 35, 26.
} 
awareness that I am forever not they, and they not I."98 In Life \& Times of Michael K (1983), the eponymous protagonist wanders the rocky Karoo communing, in less vocal ways, with goats, butterflies, and pumpkins, and is thought to be "like a stone, a pebble that, having lain around quietly minding its own business since the dawn of time, is now suddenly picked up and tossed randomly from hand to hand." 99 The Magistrate in Waiting for the Barbarians (1980) stares at the walls of his granary prison trying to hear their testimony of earlier tortures, "unable to believe that the imprint of all the pain and degradation they have enclosed will not materialize under an intent enough gaze." ${ }^{100}$ In Age of Iron (1990), Elizabeth Curren engages in etymological speculations about the deadening words of Afrikaner politicians she hears on television, about the nonhuman drift of their "stupor" and "stupidity": "From stupere, to be stunned, astounded. A gradient from stupid to stunned to astonished, to be turned to stone. The message: that the message never changes. A message that turns people to stone." 101

Nonhuman witnesses can augment narratives of historical trauma by amplifying the imaginative potential of witnessing to include an object world not commonly viewed as proffering testimony. Nonhuman testimony may be thought of as transitive (witness to specific moments of violence) or intransitive (witnessing in search of a direct object). If our theories of witnessing are incomplete to the extent that they ignore the testimonial capacity of the natural world, this results from both an insufficient interest in object materiality and an appeal to depicted violence rather than the delayed damage that postdates a conflict. Nonhuman witnesses, I have claimed, offer a way to counter the representational difficulties of ecological (as well as more immediate) violence. Following Coetzee's language in describing objects in terms of their enduring marks or traces is, of course, to assess the relevance of objects by adopting a human trope (inscription). Nevertheless, the project of ecology - a project forwarded by humans - still needs nonhuman partners and beneficiaries, whether we see them as recalcitrant and inaccessible (as in object-oriented ecology) or as an unjustly occulted sphere (as in postcolonial ecocriticism). Ecological action will surely count attestants among its participants, along networks of many scales that include oxen, cows, and bees, and the materials by which we work out our entanglements with them: paper, ink, carbon, screens, and airwaves.

\section{Acknowledgments}

One last litany, in gratitude to those who commented on earlier versions of this essay: Elizabeth S. Anker, Marta Figlerowicz, Jeanne-Marie Jackson, Marika Knowles, Yi-Ping Ong, Matthew Spellberg, Hannah Walser, and Moira Weigel.

\section{Disclosure statement}

No potential conflict of interest was reported by the author.

\footnotetext{
${ }^{98}$ Ibid., 114, 48.

${ }^{99}$ Life \& Times of Michael K, 135.

${ }^{100}$ Waiting for the Barbarians, 79.

${ }^{101}$ Age of Iron, 29.
} 


\section{Notes on contributor}

Daniel Williams is a Junior Fellow at the Harvard Society of Fellows. His articles on aspects of Victorian literature, science, and aesthetics have appeared in NOVEL: A Forum on Fiction, ELH, Victorian Poetry, Nineteenth-Century Contexts, and Genre. He also has work published or forthcoming on twentieth- and twenty-first-century British and South African literature in Anglia and Studies in the Novel, among other venues. He is currently working on a book about uncertainty in the nineteenth-century British novel, alongside developments in science, philosophy, and the law.

\section{ORCID}

Daniel Williams (D) http://orcid.org/0000-0001-7622-9176

\section{References}

Adorno, Theodor W. “Parataxis: On Hölderlin's Late Poetry." In Notes to Literature. Vol. 2, ed. Rolf Tiedemann, trans. Shierry Weber Nicholsen, 109-49. New York: Columbia University Press, 1992. Agamben, Giorgio. The Remnants of Auschwitz: The Witness and the Archive. Trans. Daniel HellerRoazen. New York: Zone Books, 2002.

Agamben, Giorgio. The Time That Remains. Trans. Patricia Dailey. Stanford, CA: Stanford University Press, 2005.

Agamben, Giorgio. Profanations. Trans. Jeff Fort. New York: Zone Books, 2007.

Alber, Jan. "Absurd Catalogues: The Functions of Lists in Postmodernist Fiction." Style 50, no. 3 (2016): 342-58.

Ashcroft, Bill. "Habitation." New Literatures Review 34 (1997): 21-41.

Attridge, Derek. "Ethical Modernism: Servants as Others in J. M. Coetzee's Early Fiction." Poetics Today 25, no. 4 (2004): 653-71.

Attwell, David. "The Problem of History in the Fiction of J. M. Coetzee." Poetics Today 11, no. 3 (1990): 579-615.

Attwell, David. “The Labyrinth of My History': J. M. Coetzee's Dusklands.” NOVEL: A Forum on Fiction 25, no. 1 (1991): 7-32.

Attwell, David. "Coetzee's Estrangements." NOVEL: A Forum on Fiction 41, no. 2/3 (2008): 229-43.

Beinart, William. The Rise of Conservation in South Africa: Settlers, Livestock, and the Environment 1770-1950. Oxford: Oxford University Press, 2003.

Belknap, Robert. “The Literary List: A Survey of its Uses and Deployments.” Literary Imagination 2, no. 1 (2000): 35-54.

Benjamin, Walter. “Dostoyevsky's The Idiot." In Selected Writings: 1913-1926, ed. Marcus Bullock and Michael W. Jennings, 78-81. Cambridge, MA: Harvard University Press, 1996.

Bennett, Jane. "The Force of Things: Steps Toward an Ecology of Matter." Political Theory 32, no. 3 (2004): 347-72.

Bennett, Jane. Vibrant Matter: A Political Ecology of Things. Durham, NC: Duke University Press, 2010.

Bennett, Jane. "Systems and Things: A Response to Graham Harman and Timothy Morton." New Literary History 43, no. 2 (2012): 225-33.

Bethlehem, Louise. "A Primary Need as Strong as Hunger': The Rhetoric of Urgency in South African Literary Culture Under Apartheid." Poetics Today 22, no. 2 (2001): 365-89.

Blanchot, Maurice and Jacques Derrida. The Instant of My Death and Demeure: Fiction and Testimony. Trans. Elizabeth Rottenberg. Stanford, CA: Stanford University Press, 2000.

Bogost, Ian. Alien Phenomenology, or What It's Like to Be a Thing. Minneapolis, MN: University of Minnesota Press, 2012.

Brown, Bill. "Thing Theory." Critical Inquiry 28, no. 1 (2001): 1-22.

Brown, Bill. A Sense of Things: The Object Matter of American Literature. Chicago, IL: University of Chicago Press, 2003. 
Caruth, Cathy. Unclaimed Experience: Trauma, Narrative, and History. Baltimore, MD: Johns Hopkins University Press, 1996.

Castillo, Debra A. “Coetzee's Dusklands: The Mythic Punctum." PMLA 105, no. 5 (1990): 1108-22.

Clarkson, Carrol. J. M. Coetzee: Countervoices. Houndmills: Palgrave Macmillan, 2009.

Coetzee, J. M. Dusklands. New York: Penguin, [1974] 1996.

Coetzee, J.M. In the Heart of the Country. London: Penguin, [1977] 1982.

Coetzee, J.M. Waiting for the Barbarians. New York: Penguin, [1980] 1982.

Coetzee, J.M. Life \& Times of Michael K. New York: Penguin, [1983] 1984.

Coetzee, J.M. "The Novel Today." Upstream 6, no. 1 (1988): 2-5.

Coetzee, J.M. White Writing: On the Culture of Letters in South Africa. New Haven, CT: Yale University Press, 1988.

Coetzee, J.M. Age of Iron. New York: Penguin, [1990] 1998.

Coetzee, J.M. Boyhood: Scenes from Provincial Life. New York: Penguin, 1998.

Coetzee, J.M. Doubling the Point: J. M. Coetzee, Essays and Interviews, ed. David Attwell. Cambridge, MA: Harvard University Press, 1992.

Cohen, Esther. "Law, Folklore and Animal Lore." Past and Present 110 (1986): 6-37.

Cohen, Jeffrey Jerome. Stone: An Ecology of the Inhuman. Minneapolis, MN: University of Minnesota Press, 2015.

Cole, Andrew. “The Call of Things: A Critique of Object-Oriented Ontologies." The Minnesota Review 80 (2013): 106-18

Cole, Andrew. “Those Obscure Objects of Desire." Artforum 53, no. 10 (2015): 318-23.

Collingwood-Whittick, Sheila. "J. M. Coetzee's Dusklands: Colonialist Myth as History." Commonwealth Essays and Studies 18, no. 2 (1996): 75-89.

De Kock, Leon. "Splice of Life: Manipulations of the 'Real' in South African English Literary Culture." Journal of Literary Studies 19, no. 1 (2003): 82-102.

De Kock, Leon. "Freedom on a Frontier? The Double Bind of (White) Postapartheid South African Literature." Ariel 46, no. 3 (2015): 55-89.

Dinzelbacher, Peter. “Animal Trials: A Multidisciplinary Approach." Journal of Interdisciplinary History 32, no. 3 (2002): 405-21.

Dovey, Teresa. "Coetzee and His Critics: The Case of Dusklands." English in Africa 14, no. 2 (1987): $15-30$.

Easton, Kai. "Coetzee, the Cape and the Question of History." Scrutiny2 11, no. 1 (2006): 5-21.

Eliot, T.S. Collected Poems, 1909-1962. New York: Harcourt, 1963.

Felski, Rita. The Limits of Critique. Chicago, IL: University of Chicago Press, 2015.

Fludernik, Monica. "Descriptive Lists and List Descriptions." Style 50, no. 3 (2016): 309-26.

Forché, Carolyn, ed. Against Forgetting: Twentieth-Century Poetry of Witness. New York: W. W. Norton, 1993.

Freedgood, Elaine. The Ideas in Things: Fugitive Meaning in the Victorian Novel. Chicago, IL: University of Chicago Press, 2006.

Gardiner, Allan. "J.M. Coetzee's Dusklands: Colonial Encounters of the Robinsonian Kind." World Literature Written in English 27, no. 2 (1987): 174-84.

Gilcrest, David W. Greening the Lyre: Environmental Poetics and Ethics. Reno, NV: University of Nevada Press, 2002.

Golumbia, David. “'Correlationism': The Dogma That Never Was.” Boundary 243 , no. 2 (2016): 1-25.

Gordimer, Nadine. "Witness: The Inward Testimony." In Witness Literature: Proceedings of the Nobel Centennial Symposium, ed. Horace Engdahl, 85-98. River Edge, NJ: World Scientific, 2002.

Green, Michael. "Social History, Literary History, and Historical Fiction in South Africa." Journal of African Cultural Studies 12, no. 2 (1999): 121-36.

Hamilton, Grant. “J.M. Coetzee's Dusklands: The Meaning of Suffering." Journal of Literary Studies 21, no. 3-4 (2005): 296-314.

Harman, Graham. "Aesthetics as First Philosophy: Levinas and the Non-Human." Naked Punch 9 (2007): 21-30.

Harman, Graham. Prince of Networks: Bruno Latour and Metaphysics. Prahran: re.press, 2009.

Head, Dominic. J. M. Coetzee. Cambridge: Cambridge University Press, 1997. 
Jolly, Rosemary. “The Gun as Copula: Colonization, Rape, and the Question of Pornographic Violence in J. M. Coetzee's Dusklands." World Literature Written in English 32-33, no. 1-2 (1992): 44-55.

Knox-Shaw, Peter. “Dusklands: A Metaphysics of Violence." In Critical Perspectives on J. M. Coetzee, ed. Graham Huggan and Stephen Watson, 107-19. London: Macmillan, 1996.

Latour, Bruno. The Pasteurization of France. Trans. Alan Sheridan and John Law. Cambridge, MA: Harvard University Press, 1988.

Latour, Bruno. We Have Never Been Modern. Trans. Catherine Porter. Cambridge, MA: Harvard University Press, 1993.

Latour, Bruno. Pandora's Hope: Essays on the Reality of Science Studies. Cambridge, MA: Harvard University Press, 1999.

Latour, Bruno. Politics of Nature: How to Bring the Sciences into Democracy. Trans. Catherine Porter. Cambridge, MA: Harvard University Press, 2004.

Latour, Bruno. Reassembling the Social: An Introduction to Actor-Network Theory. Oxford: Oxford University Press, 2005.

Lear, Linda J. Rachel Carson: Witness for Nature. New York: Henry Holt, 1997.

Love, Heather. "Close but not Deep: Literary Ethics and the Descriptive Turn." New Literary History 41, no. 2 (2010): 371-91.

Lyotard, Jean-François. The Differend: Phrases in Dispute. Trans. Georges Van Den Abbeele. Minneapolis, MN: University of Minnesota Press, 1988.

Marais, Mike. "Little Enough, Less Than Little: Nothing': Ethics, Engagement, and Change in the Fiction of J. M. Coetzee." Modern Fiction Studies 46, no. 1 (2000): 159-82.

Meillassoux, Quentin. After Finitude: An Essay on the Necessity of Contingency. Trans. Ray Brassier. London: Continuum, 2008.

Milton, John. Paradise Lost. Ed. Barbara K. Lewalski. Malden, MA: Blackwell, 2007.

Morton, Timothy. Ecology Without Nature: Rethinking Environmental Aesthetics. Cambridge, MA: Harvard University Press, 2007.

Morton, Timothy. “An Object-Oriented Defense of Poetry." New Literary History 43, no. 2 (2012): 205-24.

Mossop, E. E., ed. and trans. The Journals of Jacobus Coetsé Jansz. (1760) and Willem van Reenen (1791). Cape Town: The Van Riebeeck Society, 1935.

Mphahlele, Ezekiel [Es'kia]. "African Writers and Commitment." In Voices in the Whirlwind and other Essays, 185-98. London: Palgrave Macmillan, 1972.

Ndebele, Njabulo. "Redefining Relevance." In South African Literature: Rediscovery of the Ordinary, 60-74. Manchester: Manchester University Press, 1994.

Nixon, Rob. Slow Violence and the Environmentalism of the Poor. Cambridge, MA: Harvard University Press, 2011.

Parry, Benita. "Speech and Silence in the Fictions of J. M. Coetzee." In Writing South Africa: Literature, Apartheid, and Democracy, 1970-1995, ed. Rosemary Jolly and Derek Attridge, 149-65. Cambridge: Cambridge University Press, 1998.

Penn, Nigel. The Forgotten Frontier: Colonist and Khoisan on the Cape's Northern Frontier in the Eighteenth Century. Athens, OH: Ohio University Press, 2005.

Pietz, William. "Death of the Deodand: Accursed Objects and the Money Value of Human Life." RES 31 (1997): 97-108.

Poyner, Jane. J. M. Coetzee and the Paradox of Postcolonial Authorship. Farnham: Ashgate, 2009.

Pratt, Marie-Louise. Imperial Eyes: Travel Writing and Transculturation. London: Routledge, 1992.

Rawson, God. Gulliver, and Genocide: Barbarism and the European Imagination, 1492-1945. Oxford: Oxford University Press, 2001.

Richardson, Brian. "Modern Fiction, the Poetics of Lists, and the Boundaries of Narrative." Style 50, no. 3 (2016): 327-41.

Schreiner, Olive. The Story of an African Farm. London: Penguin, [1883] 1983.

Shapiro, Barbara J. "Beyond Reasonable Doubt" and "Probable Cause": Historical Perspectives on the Anglo-American Law of Evidence. Berkeley, CA: University of California Press, 1991.

Shaviro, Steven. The Universe of Things: On Speculative Realism. Minneapolis, MN: University of Minnesota Press, 2014. 
Stone, Christopher D. Should Trees Have Standing? And Other Essays on Law, Morals and the Environment. Dobbs Ferry, NY: Oceana, 1996.

Trimble, Stephen, and Terry Tempest Williams, comp. Testimony. Minneapolis, MN: Milkweed Editions, 1995.

Twidle, Hedley. "In a Country where You couldn't Make this Shit up'?: Literary Non-Fiction in South Africa." Safundi 13, no. 1-2 (2012): 5-28.

Vaughan, Michael. "Literature and Politics: Currents in South African Writing in the Seventies." Journal of Southern African Studies 9, no. 1 (1982): 118-38.

Von Contzen, Eva. “The Limits of Narration: Lists and Literary History." Style 50, no. 3 (2016): 241-60.

Voss, A.E. "The Image of the Bushman in South African English Writing of the Nineteenth and Twentieth Centuries." English in Africa 14, no. 1 (1987): 21-40.

Watson, Stephen. "Colonialism and the Novels of J. M. Coetzee." Research in African Literatures 17, no. 3 (1986): 370-92.

Webb, G. Gregg. "The Law of Falling Objects: Byrne v. Boadle and the Birth of Res Ipsa Loquitur." Stanford Law Review 59 (2007): 1065-109.

Wittenberg, Hermann. “Towards an Archaeology of Dusklands." English in Africa 38, no. 3 (2011): $71-89$.

Wood, W.J.B. “Dusklands and 'The Impregnable Stronghold of the Intellect." Theoria 54 (1980): 13-23.

Wordsworth, William. The Thirteen-Book Prelude. Vol. 1, ed. Mark L. Reed. Ithaca, NY: Cornell University Press, 1991.

Wu, Duncan and Carolyn Forché, eds. Poetry of Witness: The English Tradition, 1500-2001. New York: W. W. Norton, 2014.

Zimbler, Jarad. J. M. Coetzee and the Politics of Style. Cambridge: Cambridge University Press, 2014. 